\title{
Evaluation of trace elements mobility from soils to sediments between the Iberian Pyrite Belt and the Atlantic Ocean
}

\author{
M.J. Batista ${ }^{\text {a,* }}$, M.M. Abreu ${ }^{\text {b }}$, J. Locutura ${ }^{\text {c }}$, D. De Oliveira ${ }^{\text {a,e }}$, J.X. Matos ${ }^{\text {a }}$, C. Silva ${ }^{\text {a }}$, A. Bel-Lan ${ }^{\text {c }}$, L. Martins ${ }^{\text {d }}$ \\ a LNEG, Unidade de Recursos Minerais e Geofisica, Ap. 7586, 2721-866 Alfragide, Portugal \\ b Unidade de Investigação de Química Ambiental (UIOA), Instituto Superior de Agronomia, TU Lisbon, Tapada da Ajuda, $1349-017$ Lisboa, Portugal \\ ' Intituto Geologico e Minero de España, R. Rio Rosas, Madrid, Spain \\ ' Direcção Geral de Energia e Geologia, Av. 5 de Outubro, no 87, 1069-039 Lisboa, Portugal \\ e CREMINER, (Centro de Recursos Minerais, Mineralogia e Cristalografia), Faculdade de Ciências Universidade de Lisboa, Ed. C6, piso 3, 1749-016 Lisboa, Portugal
}

\section{A R T I C L E I N F O}

\section{Article history:}

Received 23 November 2011

Accepted 8 June 2012

Available online 23 June 2012

\section{Keywords:}

Physical and chemical mobility

Guadiana River basin

Iberian Pyrite Belt

\begin{abstract}
A B S T R A C T
An environmental study was conducted in 193 stream sediments and 355 soil samples collected in the lower section of Guadiana River Basin to evaluate the trace elements transfer from one compartment into another. The objective was to evaluate the dispersion of $\mathrm{Pb}, \mathrm{Cu}, \mathrm{Zn}$ and other chemical elements resulting from upstream mines into the lower N-S sector of the Guadiana River Basin to the Atlantic Ocean. The area partly includes the Iberian Pyrite Belt, a known volcanogenic massive sulphide (VMS) province with important mining activity history. Median concentrations of the elements $\mathrm{Cu}, \mathrm{Pb}, \mathrm{Zn}, \mathrm{Al}, \mathrm{As}, \mathrm{Ba}, \mathrm{Br}, \mathrm{Ca}, \mathrm{Mg}, \mathrm{Mn}$ and $\mathrm{Na}$ are generally higher in the studied sediments than in soils. Soils are normally acidic and mobility of elements is in these conditions higher. When the relations between upstream soils and downstream sediments were established, median values were higher in the upstream soils only for elements such as $\mathrm{Co}, \mathrm{Ni}, \mathrm{K}, \mathrm{Pb}, \mathrm{Mn}$ and $\mathrm{Ti}$, probably the less mobile, and the $\mathrm{Cu}, \mathrm{Zn}, \mathrm{Al}, \mathrm{As}, \mathrm{Ba}, \mathrm{Br}, \mathrm{Ca}, \mathrm{Cr}, \mathrm{Fe}, \mathrm{Mg}$ and $\mathrm{Na}$ have highest concentrations in the downstream sediments.

Lead was considered the less mobile element and $\mathrm{Zn}$ the highly mobile of the base metals in the mining area of the lower Guadiana River. Dispersion of the metals, considering the studied soil and sediment samples is partially restricted to the mining areas or downstream sediments but close to the mine sources, where ore tailings and acid waters occur. Near the mouth, concentrations of $\mathrm{As}, \mathrm{Cu}, \mathrm{Pb}$ and $\mathrm{Zn}$ increase in relation with mining and other pollution sources. Interaction with salt water forces chemical elements precipitation from water and subsequent increase of their concentration in sediments. This may be the reason for the increase of those chemical elements concentrations in the sediments.
\end{abstract}

(c) 2012 Elsevier B.V. All rights reserved.

\section{Introduction}

Rocks and soils are the main source of metallic and metalloid elements to the sediments in not highly populated basins, such as the lower sector of the Guadiana River basin. Mineralization contributes greatly to increase chemical element concentrations in soils and sediments. In the Iberian Pyrite Belt most of the mineralizations are base metals sulphide-rich, in which $\mathrm{Cu}$ and $\mathrm{Zn}$ are among the most important metals exploited and $\mathrm{Pb}$ one of the most important metals in the waste materials of the abandoned mines. Copper can be relatively immobilized in soils but its fixation processes (adsorption, occlusion and co-precipitation, organic chelation and complexing, microbial fixation), among other soil parameters, can be controlled by pH (KabataPendias and Pendias, 2001).

\footnotetext{
* Corresponding author.

E-mail addresses: mjoao.batista@lneg.pt (M.J. Batista), manuelaabreu@isa.utl.pt (M.M. Abreu).
}

Lead sulphides oxidize relatively slowly when exposed to the surface environment, but it results in $\mathrm{Pb}$ release which can be incorporated and/or adsorbed in clay-rich minerals, iron and manganese oxides and organic matter in the soils. The capacity of the soil to adsorb $\mathrm{Pb}$ increases with $\mathrm{pH}$ and cation exchange capacity, therefore only a small fraction of the total $\mathrm{Pb}$ concentration is mobilized. Surface runoff, which can transport soil particles containing adsorbed $\mathrm{Pb}$, facilitates migration and accumulation in downstream sediments. Olade (1987) reported that $\mathrm{Pb}$ natural geochemical cycles, compared with $\mathrm{Zn}$ and $\mathrm{Cd}$, in tropical environments, are similar but mobility and elements chemical forms are different. Consequently, $\mathrm{Pb}$ mobility from soil to sediments takes longer than for other chemical elements. The higher total percentages of $\mathrm{Zn}$ in soils and sediments in general are associated with iron and manganese oxides (Chao and Theobald, 1976). Rainfall removes $\mathrm{Zn}$ from soils due to its high mobility, especially at low pH (Olade, 1987).

The Iberian Pyrite Belt has a very long history of mining and smelting around the most important mining districts, such as S. Domingos and Aljustrel in Portugal and Rio Tinto and Tharsis in Spain. This history 
carries an environmental legacy that was not overcome yet; this way the soils in the vicinity of these mines are still polluted. Nevertheless, studies developed by Chopin and Alloway (2007) show that in Rio Tinto, Tharsis and in the surroundings of Huelva smelter, one of the greatest smelters in the world, the elevated concentrations of trace metals usually present in the massive sulphide ores are only restricted to nearest the mines and smelting areas. Nevertheless, one have in mind that background or natural concentrations may not be possible, in broader areas, due to the long history of mining that introduced an important footprint in the regional environment.

The mobility of solid phases from soils to sediments depends on the physiographic characteristics of the basin, such as topography, land use and vegetation cover (Rose et al., 1979). Chemical elements can be mobilized from the mining areas by physical processes associated to particulate matter, transported in suspension, or even, as chemical species in solution and later deposited in sediments or precipitated, respectively. The resistance of the ore minerals to weathering is important in exploration studies and their susceptibility to weathering increases from carbonates-silicates-oxides to sulphides. Sulphides are the most important mineralizations of the Iberian Pyrite Belt, which contribute to release and spreading of base metals by weathering processes. These conditions are very heterogeneous in the lower sector of the Guadiana River Basin where the marine influence is observed far upstream. Dams and small reservoirs play an important role in preventing the downstream movement of sediments. In the Guadiana River basin, there are several dams some with 60000 square kilometres of area while others are small reservoirs less than five square kilometres of area.

The mobility of $\mathrm{Pb}$ in the soils and sediments of Guadiana basin was also studied during a survey included in the UTPIA/SP5.P9/02 INTERREG IIIA project, which comprised an area located in the lower sector of the Guadiana basin (Batista et al., 2007). The results of that study showed that, in case of soils and sediments, mobility of $\mathrm{Pb}$ was restricted to the mining districts or to the mouth of the river. Several other studies were published where mobility of $\mathrm{Pb}$ and its source was traced until the Atlantic Ocean in different media, river water, stream water, stream and estuarine sediments, bivalves of fresh and marine water, recurring to chemical and isotopic analysis (Batista et al., 2010; Company et al., 2008; Delgado et al., 2010; Pérez-López et al., 2010) confirming that $\mathrm{Pb}$, although in low concentrations, shows a mine-related signature.

The objective of the present study was to observe the different mobility conditions of trace elements, such as $\mathrm{Cu}, \mathrm{Pb}$ and $\mathrm{Zn}$ in subcatchment areas of the Guadiana River basin and evaluate the resulting anomalies in the catchment areas.

To achieve these goals, soil and sediment samples were analyzed, being upstream versus downstream-related soil and sediment samples selected from the catchment areas. A comparison was made between catchments with or without mines. Sediment samples were also collected in the biggest water bodies like the Guadiana River and the Chança dam to compare their sediment elements concentrations with those collected in the main river, where water is flowing. High and low flow of water conditions in the Guadiana River basin was also tested by two seasonal sampling along the river.

\section{Description of the study area}

The Guadiana River rises in the Ruidera lagoons in the Campo de Montiel plain at $1700 \mathrm{~m}$ a.m.s.l. and flows $801 \mathrm{~km}$ to the Atlantic Ocean. The last $110 \mathrm{~km}$ forms the border between Portugal and Spain. In Spain the Guadiana River catchment extends in an E-W direction whereas in Portugal it runs N-S. The river is divided, from the morphological point of view, in five distinct sections: Alto Guadiana or Ruidera lagoons, the Miocene aged Mancha plain, "Monte do Toledo", Central Extremadura and finally the Portuguese section (Feio, 1951). The study area is located in the lower section of the catchment basin running N-S down to the mouth of the river (Fig. 1). The Guadiana River Basin occupies a total area of $66850 \mathrm{~km}^{2}$ in Spain and Portugal, of which $8350 \mathrm{~km}^{2}$ includes and corresponds to a part of the Iberian Pyrite Belt (IPB); one of the world's most important provinces for volcanogenic massive sulphide deposits (Leistel et al., 1997; Ribeiro et al., 1990).

The IPB consists of three main groups of rocks. The oldest formation, the Phyllite-Quartzite (PQ) Group (Upper Devonian) is made up of a thick sequence of sandstones and shales. The Upper Devonian is also represented by the Atalaia and Duque formations of quartzwackes, quartzites and phyllites, overlain by the Volcanic Sedimentary Complex (Upper Devonian). This group hosts the massive sulphide deposits and consists of volcanic rocks and metal-rich shales. Both Devonian sequences are overlain by unmineralized Carboniferous shales and sandstones of the Culm Sequence that covers most of the southern part of the Lower Guadiana Basin. The study area also includes the Pulo do Lobo Group (Lower Devonian) (Oliveira, 1990).

Near the Guadiana River mouth the Paleozoic formations change into sediments of the Meso-Cenozoic Algarve basin represented locally by: Triassic sandstones and volcanic rocks; Jurassic limestones; Miocene sandstones, Holocene beaches and wetlands.

The Paleozoic rocks between Ayamonte and Huelva are covered by detritical sediments of Tertiary-Quaternary age (Leyva and Ramirez, 1979; Salazar Rincón, 2006). Vermelha formation is a thin formation that consists of low angle alluvial cones draining in a general ENE-WSW orientation. The source of these sediments may be the nearby IPB or from further upstream which have been deposited along the Cadiz Gulf (Leyva and Ramirez, 1979; Salazar Rincón, 2006). Fig. 1 represents the geological setting of the region.

\section{Methodology}

Soils and sediments sampling was carried out in three small areas on the west side of the basin in Portugal and one big area $\left(900 \mathrm{~km}^{2}\right)$ in the east side of the basin in Spain. To observe if the areas were uniformly sampled in each sub-area, a $\chi^{2}$ test was performed. This way, the observed points correspond to the sampling sites. The sub-areas, divided in equal parts, were expected to have the same sampling sites. This calculation is given by Davis (1986):

$$
X^{2}=\Sigma \frac{(O-E)^{2}}{E}
$$

O Number of observed sites;

E Number of expected sites given by the formula: $\mathrm{E}=$ total of sampling sites/number of sub areas

Degrees of freedom is $v$

$v=(T-2)$

For two degrees of freedom, there were four sub-areas of $232 \mathrm{~km}^{2}$, $97 \mathrm{~km}^{2}, 400 \mathrm{~km}^{2}$ in Portugal and of $900 \mathrm{~km}^{2}$ in Spain where the critical value is 5.99 at the $95 \%$ confidence level. In this case, one sample per $5 \mathrm{~km}^{2}$ of soil and one sample per $10 \mathrm{~km}^{2}$ of sediments density was uniform in all areas and the values observed (5.58 for soils and 4.63 for sediments) did not exceed the critical value.

Sampling of sediments and topsoils (referred below just as soils) at $0-20 \mathrm{~cm}$ depth was carried out at 191 and 353 sites, respectively.

Chemical analysis of soils and sediments were performed after drying at less than $40^{\circ} \mathrm{C}$, sieving at less than $2 \mathrm{~mm}$ and milling, using Instrumental Neutron Activation Analysis (INAA) (As, Au, Ba, $\mathrm{Br}, \mathrm{Ce}, \mathrm{Co}, \mathrm{Cr}$, Eu, Fe, Hf, Hg, Ir, La, Lu, Na, Nd, Rb, Sb, Sc, Se, Sm, Sn, $\mathrm{Ta}, \mathrm{Th}, \mathrm{Tb}, \mathrm{U}, \mathrm{W}, \mathrm{Yb}$ ) and Inductively Coupled Plasma Optical Emission Spectrometry (ICP-OES) after digestion by $\mathrm{HCl}+\mathrm{HNO}_{3}+\mathrm{HF}+\mathrm{HClO}_{4}$ 


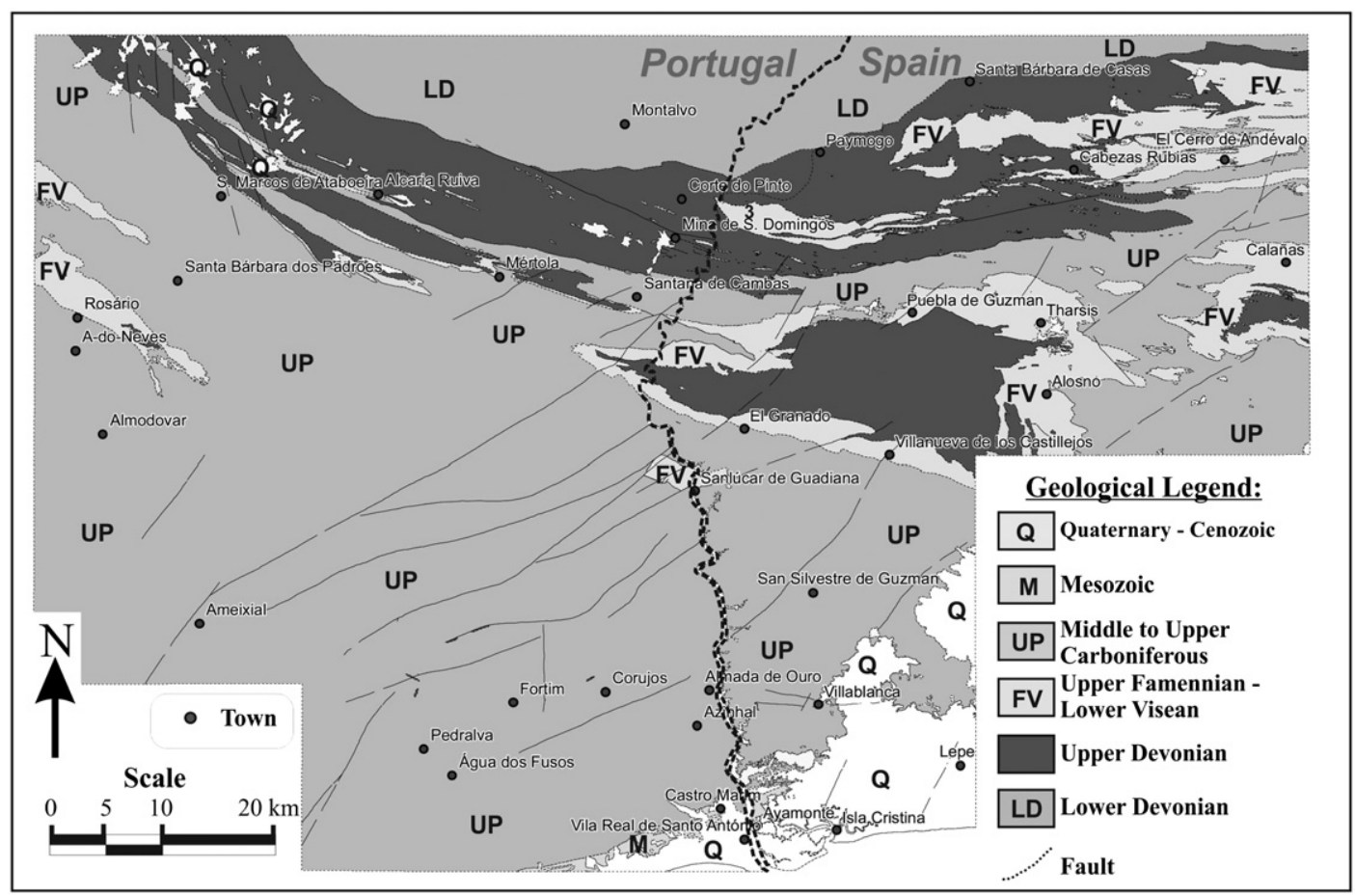

Fig. 1. Geological map of the Lower Sector of Guadiana River Basin.

for the elements $\mathrm{Ag}, \mathrm{Al}, \mathrm{Be}, \mathrm{Bi}, \mathrm{Ca}, \mathrm{Cd}, \mathrm{Cu}, \mathrm{K}, \mathrm{Mg}, \mathrm{Mn}, \mathrm{Mo}, \mathrm{Ni}, \mathrm{P}, \mathrm{Pb}, \mathrm{S} . \mathrm{Sr}$, $\mathrm{Ti}, \mathrm{V}, \mathrm{Y}$ and $\mathrm{Zn}$. Soil pH was measured in water suspension $(1: 2.5 \mathrm{w} / \mathrm{v})$ and organic carbon by wet combustion.

Quality control for soil chemical analyses consisted of analytical replicates where no significant deviation original-replicate measurement (ratio between 0.8 and 1.2). Certified Reference Materials (CRMs) where used for INNA analysis (DMMAS) where six repetitions were made and the accuracy (1) was higher $(R<5 \%)$ for $\mathrm{Au}$, As, $\mathrm{Co}, \mathrm{Cr}, \mathrm{Fe}, \mathrm{Sc}$, La, Sm.

$R_{\mathrm{r}} \%=\left|\frac{\mu-\bar{X}}{\mu}\right| x 100$

where:

$\mu \quad$ standard value given by the laboratory,

$\bar{X} \quad$ mean of determinations;

CRMs for ICP-OES analyzed elements were determined with several reference materials and one reading for each relation between certified value and measured value was good (0.85-1.1) for all elements, except for $\mathrm{Al}$ and $\mathrm{P}$. Elements such as $\mathrm{Ag}, \mathrm{Cd}, \mathrm{Bi}, \mathrm{Be}$ and $\mathrm{Mo}$ with low concentrations were not considered due to below detection limit values measured in the reference materials. In Method Blank analyses no value was reported equal or above detection limit.

The samples from upstream soils and sediments and the corresponding downstream sediments were identified and selected in a GIS mapping operation, using the criteria that only the nearest ones were selected (Fig. 2). The objective was to observe mean and median values of the upstream samples compared with downstream ones. Mineralization in the catchment area and samples collected in dams and in the Guadiana River were identified because they indicate element concentrations transported to the main river bed or retained in big dams. Soil characteristics such as $\mathrm{pH}$ and organic matter influence the mobility or capture of elements in soils and these parameters were included in the soil set of parameters. Sediment variations in concentration of certain elements were also observed by sampling in high and low flow of water in the Guadiana River, called winter and summer sampling at seven sites along the river from Chança dam to the estuarine sediments of the river mouth. One exercise was tested by selecting two samples collected in Chança reservoir near the base metal mines of S. Domingos on the Portuguese side and Vuelta Falsa and Trimpancho Group of mines on the Spanish area and two samples collected downstream from the previous two samples to evaluate the behavior of sediment concentrations near or far from large water bodies.

Basic statistics were calculated to evaluate the behavior of the total population of soils and sediments. Sediments were normalized with Al concentrations to attenuate the effect of grain size. Several methods are usually tested to normalize trace elements in the sediments catchments. Conservative elements such as aluminium and iron are usually used because they are also, after silica, the most abundant and with the proportions in general constant in the Earth's crust (Taylor, 1964; Turekian and Wedepohl, 1961). Aluminium is a major component of the clay minerals, usually aluminosilicate minerals. To meet sufficient requirements for using $\mathrm{Al}$ as the normaliser in the present study normally distributed sample data were needed, which was assessed by log transformation, when necessary, of uncontaminated sediment samples, which was determined when comparing upstream-downstream sediments. Linear correlation between the metals and Al needs to be elevated, this was not achieved for $\mathrm{Al}$, but the same exercise was done for Fe and Sc which were low as well. Therefore, and under the different conditions, $\mathrm{Al}$ seemed to be the best option for normalization. The statistical methodology used is based on the assumption that data are normally distributed. Histograms and probability curves were drawn to evaluate the normality of the populations of chemical elements. Logarithmic transformations were later performed on the variables that were not normally distributed. The means were compared using a Student $t$-test $(p<0.05)$ to prove whether the variables between upstream and downstream soils and sediments were different or not. The Student $t$ - and Levene's tests were conducted to assess the homogeneity of the variance. If the $p$-value of Levene's test is less than the critical value, 


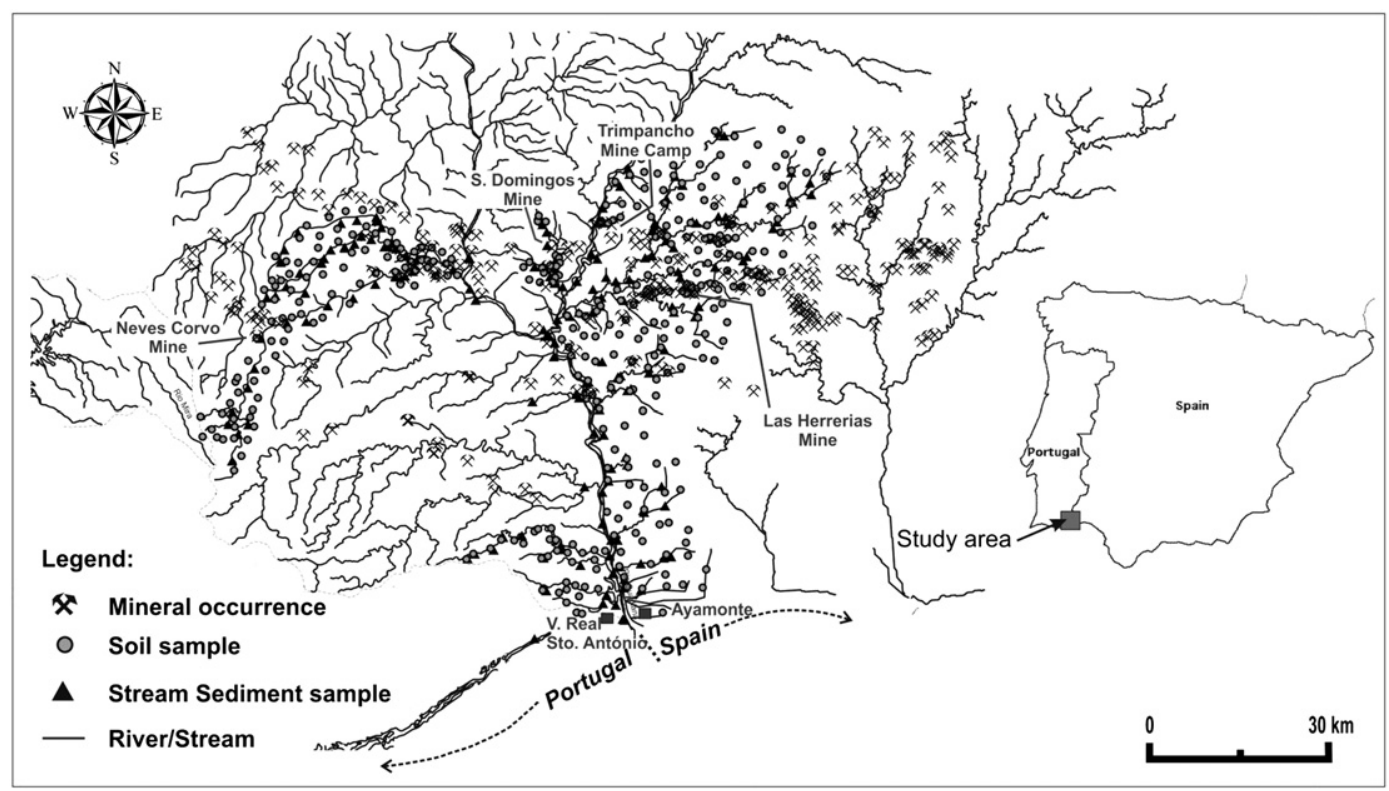

Fig. 2. Samples location within the catchment areas of the Lower Sector of Guadiana River Basin.

the null hypothesis of equal variances is rejected and there is a difference between the variances in the population. Statistical treatment of data was performed using Statsoft STATISTICA 6.0 software.

\section{Results and discussion}

The study of the total set of soils (355) and sediments (191) concentrations of the elements $\mathrm{Al}, \mathrm{As}, \mathrm{Ba}, \mathrm{Br}, \mathrm{Ca}, \mathrm{Co}, \mathrm{Cr}, \mathrm{Cu}, \mathrm{Fe}, \mathrm{K}, \mathrm{Mg}$, Mn, $\mathrm{Na}, \mathrm{Ni}$, $\mathrm{Pb}$, Ti, and $\mathrm{Zn}$, without observing upstream -downstream relations, show that median concentrations are, in general, higher in sediments, except for Ba, Co, Cr, Fe, K, Ni and Ti (Tables 1 and 2). Soil and sediment samples had, respectively, two and three times higher elements concentrations than the crustal mean values and metasedimentary rocks in general (Levinson, 1980). Lead concentrations are between 13 and 29 times higher than crustal values. Arsenic concentrations are 40 times higher than crustal values in soils and 2.5 times higher than sediments. Zinc, $\mathrm{Br}$ and $\mathrm{Mn}$ are also higher than crustal values and $\mathrm{Zn}$ is lower than metasediments. Barium, $\mathrm{Co}, \mathrm{Cr}$ and Ti have similar concentrations to the crustal mean values and $\mathrm{Ni}$ has lower concentrations than the crustal mean (Levinson, 1980). The results obtained for soils in this study were lower than the results for the Spanish side of the called South Portuguese Zone for As, $\mathrm{Cu}, \mathrm{Pb}$ and Zn (Galán et al, 2008).

The mean organic carbon content of the analyzed soil samples was $13.3 \mathrm{~g} \mathrm{~kg}^{-1}$. The organic carbon content analyzed and compared with concentrations in other regions corresponds to the lowest concentrations mapped in soils across Portugal and Spain (Jones et al., 2004). Organic carbon is low and may not be responsible for the retention of the chemical elements in the studied soils. On the other hand, the soils have a mean $\mathrm{pH}$ of 5.55 , which is rather acid and helps the mobilization of elements such as $\mathrm{Cu}, \mathrm{Zn}$ and even less mobile elements such as Pb (Nriagu, 1990; Wilson and Bell, 1996).

When the relations between upstream soils and downstream sediments are established, the mean concentrations are higher in upstream soils for $\mathrm{Co}, \mathrm{K}, \mathrm{Mn}, \mathrm{Ni}, \mathrm{Pb}$ and $\mathrm{Ti}$ and higher in downstream sediments for $\mathrm{Al}, \mathrm{As}, \mathrm{Ba}, \mathrm{Br}, \mathrm{Ca}, \mathrm{Cr}, \mathrm{Cu}, \mathrm{Fe}, \mathrm{Mg}$, Na, $\mathrm{Zn}$ (Table 3). The median values are higher in the upstream soils only for $\mathrm{Co}, \mathrm{Cr}, \mathrm{K}$, $\mathrm{Mn}, \mathrm{Ni}$, and $\mathrm{Ti}$, and the remaining elements $\mathrm{Al}, \mathrm{As}, \mathrm{Ba}, \mathrm{Br}, \mathrm{Ca}, \mathrm{Cu}, \mathrm{Fe}$, $\mathrm{Mg}, \mathrm{Na}, \mathrm{Pb}$ and $\mathrm{Zn}$, have the highest median concentrations in the downstream sediments. Olade (1987) and Hall et al. (2001) reported that geochemical cycles of $\mathrm{Pb}$ were slower compared with those of $\mathrm{Zn}$

Table 1

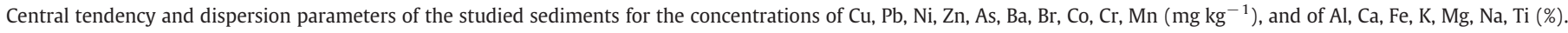

\begin{tabular}{|c|c|c|c|c|c|c|c|c|c|c|}
\hline & \multirow{2}{*}{$\begin{array}{l}\text { N. } \\
\text { Samp. }\end{array}$} & \multirow[t]{2}{*}{ Minimum } & \multicolumn{3}{|c|}{ Central tendency parameters } & \multirow[t]{2}{*}{ Maximum } & \multicolumn{4}{|c|}{ Dispersion parameters } \\
\hline & & & Mean & Geometric & Median & & Variance & Std. Dev. & Skewness & Kurtosis \\
\hline $\mathrm{Cu}$ & 191 & 3.00 & 51.16 & 36.69 & 33.00 & 607.00 & 4210.73 & 64.89 & 4.78 & 31.01 \\
\hline $\mathrm{Pb}$ & 191 & 7.00 & 102.26 & 34.32 & 27.00 & 5000.00 & 195735.17 & 442.42 & 8.99 & 89.48 \\
\hline $\mathrm{Ni}$ & 193 & $<1.00$ & 38.24 & 34.24 & 38.00 & 123.00 & 241.81 & 15.55 & 1.50 & 8.28 \\
\hline Zn & 193 & $<1.00$ & 94.73 & 78.88 & 75.00 & 512.00 & 4296.93 & 65.55 & 2.86 & 10.94 \\
\hline $\mathrm{Al}$ & 191 & 0.65 & 3.42 & 3.28 & 3.22 & 10.40 & 1.16 & 1.08 & 2.71 & 14.42 \\
\hline As & 193 & 4.60 & 86.91 & 24.67 & 20.00 & 2640.00 & 104518.34 & 323.29 & 6.11 & 39.55 \\
\hline $\mathrm{Ba}$ & 193 & 50.00 & 491.87 & 432.78 & 490.00 & 1140.00 & 39225.67 & 198.05 & 0.19 & 1.04 \\
\hline $\mathrm{Br}$ & 193 & $<0.50$ & 9.45 & 4.24 & 5.20 & 126.00 & 308.15 & 17.55 & 4.50 & 22.97 \\
\hline $\mathrm{Ca}$ & 191 & 0.03 & 0.46 & 0.21 & 0.16 & 6.87 & 0.91 & 0.96 & 4.75 & 25.36 \\
\hline Co & 193 & $<1.00$ & 15.86 & 14.36 & 15.00 & 41.00 & 38.10 & 6.17 & 0.56 & 1.69 \\
\hline $\mathrm{Cr}$ & 193 & $<2.00$ & 79.11 & 72.45 & 75.00 & 275.00 & 950.80 & 30.84 & 2.06 & 11.20 \\
\hline $\mathrm{Fe}$ & 193 & 0.32 & 4.07 & 3.78 & 3.90 & 11.10 & 2.13 & 1.46 & 1.15 & 4.86 \\
\hline K & 191 & 0.37 & 1.64 & 1.58 & 1.57 & 3.31 & 0.19 & 0.44 & 0.71 & 1.88 \\
\hline $\mathrm{Mg}$ & 191 & 0.07 & 0.80 & 0.72 & 0.76 & 2.97 & 0.17 & 0.41 & 2.22 & 8.53 \\
\hline $\mathrm{Mn}$ & 191 & 64.00 & 835.99 & 710.75 & 772.00 & 3250.00 & 209637.18 & 457.86 & 1.42 & 4.41 \\
\hline $\mathrm{Na}$ & 193 & 0.09 & 0.83 & 0.73 & 0.81 & 2.48 & 0.15 & 0.39 & 0.62 & 0.99 \\
\hline $\mathrm{Ti}$ & 191 & 0.06 & 0.46 & 0.44 & 0.46 & 0.89 & 0.01 & 0.12 & -0.11 & 2.04 \\
\hline
\end{tabular}

N. Samp.-number of samples; Std. Dev.-standard deviation. 
Table 2

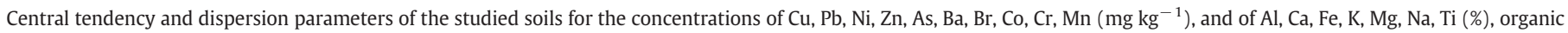
carbon $\left(\mathrm{g} \mathrm{kg}^{-1}\right)$, $\mathrm{pH}$.

\begin{tabular}{|c|c|c|c|c|c|c|c|c|c|c|}
\hline \multicolumn{11}{|l|}{ Total soils } \\
\hline & \multirow[t]{2}{*}{$N$} & \multirow[t]{2}{*}{ Minimum } & \multicolumn{3}{|c|}{ Central tendency parameters } & \multirow[t]{2}{*}{ Maximum } & \multicolumn{4}{|c|}{ Dispersion parameters } \\
\hline & & & Mean & Geometric & Median & & Variance & Std.Dev. & Skewness & Kurtosis \\
\hline $\mathrm{Cu}$ & 355 & 3.00 & 41.64 & 28.46 & 28.00 & 1190.00 & 6242.13 & 79.01 & 10.11 & 131.77 \\
\hline $\mathrm{Pb}$ & 355 & 5.00 & 133.09 & 29.94 & 25.00 & 25700.00 & 1896053.39 & 1376.97 & 18.21 & 338.50 \\
\hline $\mathrm{Ni}$ & 355 & 2.00 & 41.24 & 34.62 & 40.00 & 450.00 & 815.98 & 28.57 & 8.46 & 118.45 \\
\hline $\mathrm{Zn}$ & 355 & 9.00 & 82.80 & 64.81 & 66.00 & 2940.00 & 26406.82 & 162.50 & 15.66 & 272.22 \\
\hline $\mathrm{Al}$ & 355 & 0.71 & 3.04 & 2.90 & 2.91 & 7.66 & 0.88 & 0.94 & 1.04 & 2.83 \\
\hline As & 355 & 1.60 & 34.85 & 18.99 & 17.80 & 2570.00 & 22647.64 & 150.49 & 14.46 & 233.11 \\
\hline $\mathrm{Ba}$ & 355 & 50.00 & 476.48 & 427.80 & 500.00 & 1310.00 & 36489.54 & 191.02 & 0.38 & 1.49 \\
\hline $\mathrm{Br}$ & 355 & $<0.50$ & 3.46 & 2.76 & 3.30 & 12.80 & 4.60 & 2.15 & 1.16 & 2.21 \\
\hline $\mathrm{Ca}$ & 355 & 0.02 & 0.20 & 0.12 & 0.12 & 4.57 & 0.15 & 0.38 & 6.86 & 59.28 \\
\hline Co & 355 & $<1.00$ & 16.65 & 14.69 & 17.00 & 68.00 & 53.97 & 7.35 & 1.13 & 6.48 \\
\hline $\mathrm{Cr}$ & 355 & $<2.00$ & 81.21 & 72.41 & 79.00 & 661.00 & 1964.15 & 44.32 & 6.80 & 84.04 \\
\hline $\mathrm{Fe}$ & 355 & 0.72 & 3.91 & 3.68 & 3.92 & 12.20 & 1.72 & 1.31 & 0.99 & 5.10 \\
\hline $\mathrm{K}$ & 355 & 0.07 & 1.84 & 1.71 & 1.84 & 3.64 & 0.40 & 0.63 & 0.10 & -0.08 \\
\hline $\mathrm{Mg}$ & 355 & 0.05 & 0.56 & 0.47 & 0.49 & 5.99 & 0.19 & 0.43 & 6.34 & 71.95 \\
\hline $\mathrm{Mn}$ & 355 & 24.00 & 966.32 & 665.60 & 767.00 & 44400.00 & 5673335.75 & 2381.88 & 17.25 & 314.71 \\
\hline $\mathrm{Na}$ & 355 & 0.06 & 0.77 & 0.60 & 0.63 & 3.06 & 0.25 & 0.50 & 0.92 & 0.62 \\
\hline $\mathrm{Ti}$ & 355 & 0.09 & 0.50 & 0.48 & 0.51 & 1.24 & 0.02 & 0.14 & 0.23 & 4.24 \\
\hline $\mathrm{pH}\left(\mathrm{H}_{2} \mathrm{O}\right)$ & 353 & 2.22 & 5.55 & 5.49 & 5.52 & 8.22 & 0.55 & 0.74 & 0.03 & 1.03 \\
\hline Org. C. & 353 & 1.24 & 13.37 & 11.71 & 12.17 & 55.93 & 45.78 & 6.77 & 1.35 & 4.35 \\
\hline
\end{tabular}

N. Samp.-number of samples; Std.Dev.-standard deviation.

Table 3

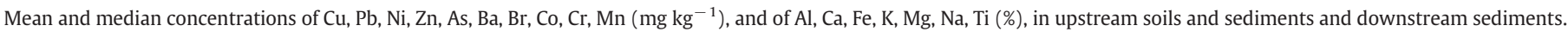

\begin{tabular}{|c|c|c|c|c|}
\hline \multirow[t]{2}{*}{ Elements } & \multicolumn{2}{|c|}{ (67) Sediments } & \multicolumn{2}{|c|}{ (97) soils upstream } \\
\hline & mean & median & mean & median \\
\hline $\mathrm{Cu}$ & 61.00 & 36.00 & 54.00 & 27.00 \\
\hline $\mathrm{Pb}$ & 177.00 & 30.00 & 330.00 & 29.00 \\
\hline $\mathrm{Ni}$ & 36.00 & 34.00 & 38.00 & 38.00 \\
\hline $\mathrm{Zn}$ & 85.00 & 70.00 & 80.00 & 64.00 \\
\hline $\mathrm{Al} \%$ & 3.28 & 3.25 & 3.00 & 3.00 \\
\hline As & 149.00 & 20.00 & 57.00 & 17.00 \\
\hline $\mathrm{Ba}$ & 492.00 & 505.00 & 459.00 & 490.00 \\
\hline $\mathrm{Br}$ & 12.00 & 5.00 & 3.10 & 3.00 \\
\hline $\mathrm{Ca} \%$ & 0.40 & 0.20 & 0.22 & 0.13 \\
\hline Co & 14.00 & 14.00 & 16.00 & 16.00 \\
\hline $\mathrm{Cr}$ & 75.00 & 73.00 & 75.00 & 74.00 \\
\hline $\mathrm{Fe}$ & 4.11 & 3.76 & 3.67 & 3.41 \\
\hline $\mathrm{K}$ & 1.58 & 1.50 & 1.70 & 1.62 \\
\hline $\mathrm{Mg}$ & 0.78 & 0.77 & 0.60 & 0.57 \\
\hline $\mathrm{Mn}$ & 786.00 & 715.00 & 868.00 & 754.00 \\
\hline $\mathrm{Na}$ & 0.87 & 0.84 & 0.86 & 0.76 \\
\hline $\mathrm{Ti}$ & 0.45 & 0.47 & 0.50 & 0.50 \\
\hline \multirow[t]{2}{*}{ Elements } & \multicolumn{2}{|c|}{ (18) Sediments } & \multicolumn{2}{|c|}{ (23) sed. upstream } \\
\hline & mean & $\overline{\text { median }}$ & mean & median \\
\hline $\mathrm{Cu}$ & 57.00 & 31.00 & 60.00 & 39.00 \\
\hline $\mathrm{Pb}$ & 58.00 & 23.00 & 79.00 & 28.00 \\
\hline $\mathrm{Ni}$ & 34.00 & 34.00 & 37.00 & 34.00 \\
\hline $\mathrm{Zn}$ & 76.00 & 62.00 & 90.00 & 69.00 \\
\hline $\mathrm{Al}$ & 3.51 & 3.53 & 3.41 & 3.37 \\
\hline As & 140.00 & 15.90 & 58.50 & 16.05 \\
\hline $\mathrm{Ba}$ & 485.00 & 490.00 & 550.00 & 585.00 \\
\hline $\mathrm{Br}$ & 7.10 & 7.40 & 11.70 & 6.25 \\
\hline $\mathrm{Ca}$ & 0.59 & 0.15 & 0.35 & 0.19 \\
\hline Co & 13.00 & 13.00 & 15.00 & 15.50 \\
\hline $\mathrm{Cr}$ & 65.00 & 60.00 & 70.00 & 67.50 \\
\hline $\mathrm{Fe}$ & 3.74 & 3.45 & 3.65 & 3.48 \\
\hline K & 1.57 & 1.51 & 1.60 & 1.56 \\
\hline $\mathrm{Mg}$ & 0.80 & 0.86 & 0.87 & 0.88 \\
\hline $\mathrm{Mn}$ & 788.00 & 741.00 & 961.00 & 966.00 \\
\hline $\mathrm{Na}$ & 0.96 & 0.88 & 1.01 & 0.99 \\
\hline $\mathrm{Ti}$ & 0.46 & 0.47 & 0.50 & 0.48 \\
\hline
\end{tabular}

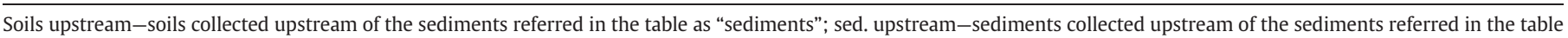
as "sediments". 
Table 4

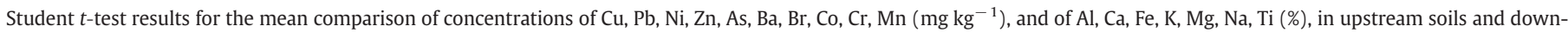
stream sediments.

\begin{tabular}{|c|c|c|c|c|c|c|c|c|c|c|c|c|}
\hline & Mean (66)sediments & Mean (97)soils & $t$-value & $d f$ & $p$ & Std. Dev. sediments & Std. Dev. soils & $F$-ratio & $p$ & Levene & $d f$ & $p^{*}$ \\
\hline $\log \mathrm{Cu}$ & 1.62 & 1.47 & 2.52 & 161 & 0.01 & 0.36 & 0.39 & 1.18 & 0.47 & 0.38 & 161 & 0.54 \\
\hline $\log \mathrm{Pb}$ & 1.61 & 1.55 & 0.79 & 161 & 0.43 & 0.55 & 0.48 & 1.30 & 0.24 & 1.93 & 161 & 0.17 \\
\hline $\mathrm{Ni}$ & 36.09 & 38.22 & -0.78 & 161 & 0.44 & 12.92 & 19.53 & 2.28 & 0.00 & 7.68 & 161 & 0.01 \\
\hline $\log Z n$ & 1.87 & 1.81 & 1.39 & 161 & 0.17 & 0.24 & 0.27 & 1.31 & 0.24 & 0.69 & 161 & 0.41 \\
\hline $\mathrm{Al}$ & 3.28 & 2.88 & 2.63 & 161 & 0.01 & 0.83 & 1.04 & 1.56 & 0.06 & 3.15 & 161 & 0.08 \\
\hline $\log A s$ & 1.47 & 1.28 & 2.49 & 161 & 0.01 & 0.58 & 0.39 & 2.21 & 0.00 & 6.49 & 161 & 0.01 \\
\hline $\mathrm{Ba}$ & 492.42 & 459.48 & 1.08 & 161 & 0.28 & 195.89 & 189.08 & 1.07 & 0.75 & 0.06 & 161 & 0.81 \\
\hline $\log B r$ & 0.71 & 0.39 & 4.58 & 161 & 0.00 & 0.55 & 0.33 & 2.86 & 0.00 & 7.81 & 161 & 0.01 \\
\hline $\log C a$ & -0.78 & -0.85 & 1.20 & 161 & 0.23 & 0.41 & 0.34 & 1.40 & 0.13 & 0.39 & 161 & 0.53 \\
\hline Co & 14.47 & 16.28 & -1.69 & 161 & 0.09 & 5.88 & 7.22 & 1.51 & 0.08 & 1.76 & 161 & 0.19 \\
\hline $\mathrm{Cr}$ & 75.08 & 74.58 & 0.12 & 161 & 0.91 & 23.43 & 29.42 & 1.58 & 0.05 & 1.22 & 161 & 0.27 \\
\hline $\mathrm{Fe}$ & 4.11 & 3.67 & 1.78 & 161 & 0.08 & 1.69 & 1.45 & 1.36 & 0.17 & 0.75 & 161 & 0.39 \\
\hline K & 1.58 & 1.71 & -1.46 & 161 & 0.15 & 0.45 & 0.61 & 1.87 & 0.01 & 8.16 & 161 & 0.01 \\
\hline $\mathrm{Mg}$ & 0.78 & 0.60 & 3.14 & 161 & 0.00 & 0.36 & 0.35 & 1.02 & 0.91 & 0.23 & 161 & 0.64 \\
\hline logMn & 2.79 & 2.80 & -0.20 & 161 & 0.85 & 0.33 & 0.40 & 1.46 & 0.10 & 0.37 & 161 & 0.54 \\
\hline $\log \mathrm{Na}$ & -0.12 & -0.18 & 1.21 & 161 & 0.23 & 0.25 & 0.34 & 1.90 & 0.01 & 11.40 & 161 & 0.00 \\
\hline $\mathrm{Ti}$ & 0.45 & 0.50 & -2.07 & 161 & 0.04 & 0.11 & 0.15 & 2.05 & 0.00 & 1.00 & 161 & 0.32 \\
\hline
\end{tabular}

Sediments-sediments collected downstream from the soils; soils-soils collected upstream from the previous referred sediments in the influence area of those sediments.

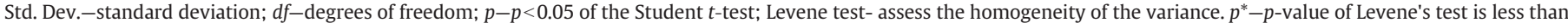
the critical value.

and $\mathrm{Cd}$ being their chemical forms different and consequently their mobility characteristics. The above cited authors demonstrated that the mobility from soil to sediments takes more time for $\mathrm{Pb}$ than for $\mathrm{Cd}$ and $\mathrm{Zn}$. These observations are in accordance with the present study where mean $\mathrm{Pb}$ concentrations are higher in upstream soils than in downstream sediments as was already observed by Batista et al. (2010).

Upstream sediments have the highest mean concentrations of most elements, except for $\mathrm{Al}, \mathrm{As}, \mathrm{Ca}$ and $\mathrm{Fe}$ whose mean concentrations are higher in downstream sediments (Table 3). Median concentrations of $\mathrm{Al}$ and $\mathrm{Br}$ are also higher in downstream sediments when compared to upstream sediments (Table 3).

Mean concentrations of $\mathrm{Al}, \mathrm{As}, \mathrm{Br}, \mathrm{Cu}, \mathrm{Mg}$ and Ti were significantly different (Student $t$-test) between upstream soils and downstream sediments (Table 4). The Student $t$-test made on the upstream sediments and downstream sediments, show no significant differences of $\mathrm{Al}, \mathrm{As}, \mathrm{Ba}, \mathrm{Br}, \mathrm{Ca}, \mathrm{Co}, \mathrm{Cr}, \mathrm{Cu}, \mathrm{Fe}, \mathrm{K}, \mathrm{Mg}, \mathrm{Mn}, \mathrm{Na}, \mathrm{Ni}, \mathrm{Pb}, \mathrm{Ti}, \mathrm{Zn}$ to the given $p<0.05$ (Table 5 ). The differences in downstream sediment chemistry from upstream soils chemical elements concentrations
(Table 4) and similarities to upstream sediments (Table 5) are probably related to similar physical-chemical behavior between sediments but not between sediments and soils.

Mobility probably occurred for elements such as $\mathrm{Al}, \mathrm{Ba}, \mathrm{Br}, \mathrm{Ca}, \mathrm{Mg}$, $\mathrm{Na}$ and $\mathrm{Zn}$ where their concentrations are higher in sediments from the main Guadiana River bed than in the effluent stream sediments downstream the mines areas. Aluminium, $\mathrm{Ba}, \mathrm{Br}, \mathrm{Ca}, \mathrm{Mg}$ and $\mathrm{Na}$ river bed sediments concentrations are even higher than in soils in the mine catchment areas (Table 6). Elements such as As, $\mathrm{Cu}$, Fe and $\mathrm{Pb}$ have higher concentration in soils in the mine catchment areas than in Guadiana river sediments but As, Fe and $\mathrm{Pb}$ have much higher concentrations in the downstream sediments in the mine's catchment.

The mechanism that controls the mobility of $\mathrm{Al}$ and Fe can be associated with Eh-pH seasonal variations that facilitate the solubility or the precipitation of $\mathrm{Fe}$ and $\mathrm{Al}$ bearing minerals such as oxyhydroxides (Violante et al., 2010). In the case of Al, the reason for elevated concentrations in Guadiana River sediments may be due to fine grain size of sediments, mainly coming from shales weathering materials or soils from the river basin. Iron variations in the water flow in smaller affluent

Table 5

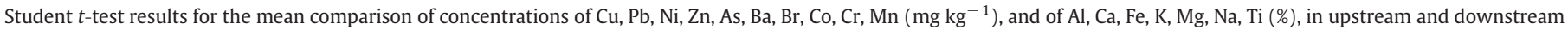
sediments.

\begin{tabular}{|c|c|c|c|c|c|c|c|c|c|c|c|c|}
\hline & $\begin{array}{l}\text { Mean } \\
\text { (24)upstream }\end{array}$ & $\begin{array}{l}\text { Mean } \\
\text { (18)downstream }\end{array}$ & $t$-value & $d f$ & $p$ & $\begin{array}{l}\text { Std. Dev. } \\
\text { upstream }\end{array}$ & $\begin{array}{l}\text { Std. Dev. } \\
\text { downstream }\end{array}$ & F-ratio & $p$ & Levene & df & $p^{*}$ \\
\hline $\mathrm{CuN}$ & 17.90 & 16.99 & 0.14 & 40 & 0.89 & 17.24 & 24.68 & 2.05 & 0.11 & 0.11 & 40 & 0.74 \\
\hline $\mathrm{PbN}$ & 23.90 & 17.35 & 0.55 & 40 & 0.59 & 41.75 & 33.50 & 1.553 & 0.36 & 0.41 & 40 & 0.53 \\
\hline $\mathrm{NiN}$ & 10.87 & 9.43 & 1.79 & 40 & 0.08 & 2.40 & 2.79 & 1.36 & 0.49 & 0.06 & 40 & 0.81 \\
\hline $\mathrm{ZnN}$ & 26.88 & 21.84 & 0.86 & 40 & 0.40 & 21.63 & 14.09 & 2.36 & 0.07 & 1.47 & 40 & 0.23 \\
\hline $\mathrm{Al}$ & 3.41 & 3.51 & -0.71 & 40 & 0.48 & 0.43 & 0.49 & 1.30 & 0.55 & 0.12 & 40 & 0.73 \\
\hline AsN & 17.82 & 47.77 & -0.88 & 40 & 0.39 & 41.34 & 160.93 & 15.16 & 0.00 & 3.50 & 40 & 0.07 \\
\hline $\mathrm{BaN}$ & 163.72 & 139.25 & 1.35 & 40 & 0.18 & 64.72 & 47.57 & 1.85 & 0.20 & 2.95 & 40 & 0.09 \\
\hline $\mathrm{BrN}$ & 3.63 & 2.09 & 0.78 & 40 & 0.44 & 8.44 & 1.50 & 31.66 & 0.00 & 1.91 & 40 & 0.18 \\
\hline $\mathrm{CaN}$ & 0.12 & 0.23 & -0.73 & 40 & 0.47 & 0.19 & 0.72 & 14.97 & 0.00 & 2.78 & 40 & 0.10 \\
\hline CoNN & 4.45 & 3.68 & 1.85 & 40 & 0.07 & 1.53 & 1.06 & 2.08 & 0.13 & 1.34 & 40 & 0.25 \\
\hline $\mathrm{CrN}$ & 20.74 & 18.34 & 1.88 & 40 & 0.07 & 4.27 & 3.86 & 1.22 & 0.68 & 0.18 & 40 & 0.67 \\
\hline $\mathrm{FeN}$ & 1.09 & 1.09 & -0.02 & 40 & 0.98 & 0.31 & 0.77 & 5.98 & 0.00 & 0.76 & 40 & 0.39 \\
\hline KN & 0.47 & 0.46 & 0.49 & 40 & 0.63 & 0.10 & 0.12 & 1.35 & 0.49 & 0.15 & 40 & 0.70 \\
\hline $\mathrm{MgN}$ & 0.26 & 0.22 & 1.74 & 40 & 0.09 & 0.07 & 0.05 & 2.03 & 0.14 & 0.30 & 40 & 0.59 \\
\hline $\mathrm{MnN}$ & 281.45 & 220.89 & 1.50 & 40 & 0.14 & 135.32 & 122.28 & 1.23 & 0.68 & 0.35 & 40 & 0.56 \\
\hline $\mathrm{NaN}$ & 0.31 & 0.28 & 0.79 & 40 & 0.44 & 0.12 & 0.08 & 2.18 & 0.10 & 1.20 & 40 & 0.28 \\
\hline TiN & 0.15 & 0.13 & 1.95 & 40 & 0.06 & 0.04 & 0.03 & 1.80 & 0.22 & 1.75 & 40 & 0.19 \\
\hline
\end{tabular}

ElementN-element normalized by Al; upstream-sediments collected upstream from others; downstream-sediments collected downstream from the previous ones.

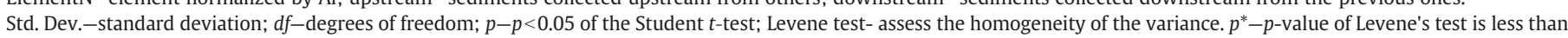
the critical value. 
Table 6

Mean and median concentrations of $\mathrm{Cu}, \mathrm{Pb}, \mathrm{Ni}, \mathrm{Zn}, \mathrm{As}, \mathrm{Ba}, \mathrm{Br}, \mathrm{Co}, \mathrm{Cr}, \mathrm{Mn}\left(\mathrm{mg} \mathrm{kg}^{-1}\right)$, and of $\mathrm{Al}, \mathrm{Ca}, \mathrm{Fe}, \mathrm{K}, \mathrm{Mg}, \mathrm{Na}, \mathrm{Ti}$ (\%), in upstream soils and downstream sediments from catchment areas with mines included and sediments from the Guadiana river.

\begin{tabular}{|c|c|c|c|c|c|c|}
\hline \multirow[t]{3}{*}{ Element } & \multicolumn{4}{|c|}{ Mines in catchment } & \multirow{2}{*}{\multicolumn{2}{|c|}{$\begin{array}{l}\text { Sed. Guadiana } \\
\text { River }\end{array}$}} \\
\hline & \multicolumn{2}{|c|}{ Soil upstream } & \multicolumn{2}{|c|}{ Sed. downstream } & & \\
\hline & Mean & Median & Mean & Median & Mean & Median \\
\hline $\mathrm{Cu}$ & 142.00 & 59.00 & 116.00 & 86.00 & 39.00 & 36.00 \\
\hline $\mathrm{Pb}$ & 171.00 & 56.00 & 360.00 & 36.00 & 32.00 & 31.00 \\
\hline $\mathrm{Ni}$ & 45.00 & 43.00 & 31.00 & 26.00 & 35.00 & 37.00 \\
\hline Zn & 128.00 & 74.00 & 85.00 & 77.00 & 120.00 & 108.00 \\
\hline $\mathrm{Al}$ & 3.54 & 3.19 & 2.78 & 2.67 & 3.60 & 3.20 \\
\hline As & 46.10 & 47.40 & 456.00 & 48.00 & 29.50 & 33.70 \\
\hline $\mathrm{Ba}$ & 495.00 & 505.00 & 428.00 & 445.00 & 557.00 & 540.00 \\
\hline $\mathrm{Br}$ & 3.70 & 3.30 & 4.76 & 4.55 & 20.50 & 10.00 \\
\hline $\mathrm{Ca}$ & 0.54 & 0.13 & 0.22 & 0.10 & 0.79 & 0.78 \\
\hline Co & 22.00 & 22.00 & 13.00 & 13.00 & 16.00 & 17.00 \\
\hline $\mathrm{Cr}$ & 94.00 & 81.00 & 85.00 & 84.00 & 79.00 & 82.00 \\
\hline $\mathrm{Fe}$ & 5.49 & 4.94 & 6.52 & 6.35 & 3.94 & 4.03 \\
\hline K & 1.85 & 1.72 & 1.49 & 1.42 & 1.65 & 1.60 \\
\hline $\mathrm{Mg}$ & 0.63 & 0.47 & 0.54 & 0.56 & 1.02 & 0.93 \\
\hline $\mathrm{Mn}$ & 1277.00 & 1375.00 & 768.00 & 476.00 & 860.00 & 809.00 \\
\hline $\mathrm{Na}$ & 0.66 & 0.34 & 0.64 & 0.59 & 1.19 & 1.30 \\
\hline $\mathrm{Ti}$ & 0.57 & 0.52 & 0.38 & 0.40 & 0.59 & 0.62 \\
\hline
\end{tabular}

Sed.-sediments.

streams can reflect precipitation-dissolution of Fe oxyhydroxides that could also incorporate $\mathrm{Pb}$ and As.

Concentrations of chemical elements observed in the sediments samples collected near or far from mines within the Chança dam area show that near S. Domingos mine (559SD09), the closest sample collected in the Chança dam area had higher concentrations of $\mathrm{As}, \mathrm{Cu}$, $\mathrm{Fe}$ and $\mathrm{Pb}$ (Table 7). This sample showed lower concentrations of $\mathrm{Al}$, $\mathrm{Mn}, \mathrm{Ti}$ and $\mathrm{Zn}$ than the sample collected downstream from the previous one in a large water body (567SD01) (Table 7). In the sample taken closer to the Spanish mines in the Chança reservoir, concentrations of $\mathrm{Al}, \mathrm{As}, \mathrm{Fe}, \mathrm{Mn}, \mathrm{Pb}$ and $\mathrm{Ti}$ were higher and $\mathrm{Cu}$ and $\mathrm{Zn}$ were lower than the concentrations of the same elements in the sediment sample collected downstream the reservoir (Table 7). The observed results of this exercise, although restricted to the present sample locations, indicate that concentrations of the chemical elements in sediments are dependent on the proximity of the mines.

The variations of water flow may also influence mobility of chemical elements in sediments. This fact was tested and can be observed in Fig. 3. Comparison of summer and winter samples show that, in general, $\mathrm{Cu}, \mathrm{Pb}$ and $\mathrm{Zn}$ are higher in sediments in winter time. This is a consequence of the high water flow that removes fine particles deposited on river bed or banks or solid phases precipitated during calmer periods, moving high contents of metals from the source sites to the downstream sediments. The highest summer and winter concentrations of $\mathrm{Cu}, \mathrm{Pb}$ and $\mathrm{Zn}$ were found in the old mine harbor at Pomarão, where ore, spilt when ships were loaded these, may still be reflected in the sediments of this harbor (Batista et al., 2010). Near the mouth of the Guadiana River different behavior was observed; $\mathrm{Zn}$ concentrations were higher in summer time than in winter and $\mathrm{Pb}$ was higher in winter than in summer time. Lead concentrations can be related with different sources, such as traffic, industry and mining (Batista et al., 2007; Company et al., 2008; Delgado et al., 2011; Pérez-López et al., 2010).

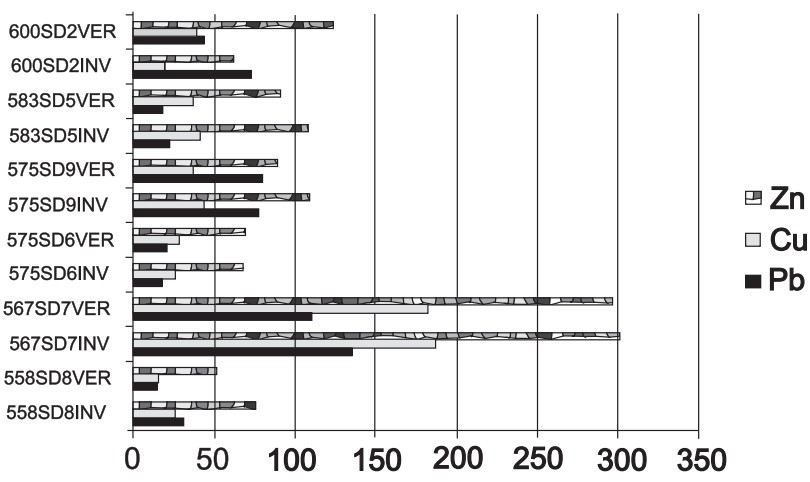

Fig. 3. Bar diagram representing seasonal sample variations of the sediments along the Guadiana River for the elements $\mathrm{Cu}, \mathrm{Pb}$ and $\mathrm{Zn}\left(\mathrm{mg} \mathrm{kg}^{-1}\right)$; sample number INV-sample number collected in winter; sample number VER-sample number collected in summer time.

In the near coastal area (mouth of Guadiana River) where fresh water meets salt water, the physical-chemical differences between them may force precipitation of elements that were in the water solution, as could be the case of $\mathrm{Zn}$. This process, along with the complex sedimentation regime due to the tidal environment, contributes to the sediments increase in $\mathrm{Pb}$ and other chemical elements, whatever their origin. Soils collected near the river mouth were developed mainly on alluvial materials and are not very different from the sediments (Batista et al., 2007; Delgado et al., 2011), this way, it is difficult to perceive the potential mobility between both compartments.

\section{Conclusions}

Median concentrations of chemical elements were, in general, higher in sediments, except for $\mathrm{Ni}, \mathrm{Ba}, \mathrm{Co}, \mathrm{Cr}, \mathrm{Fe}, \mathrm{K}$ and $\mathrm{Ti}$, than in soils collected in the Lower sector of Guadiana River basin.

When upstream soils were related with downstream sediments median concentrations of $\mathrm{Co}, \mathrm{Cr}, \mathrm{K}, \mathrm{Mn}, \mathrm{Ni}$, and Ti were higher in the upstream soils than in downstream sediments. However, the remaining elements ( $\mathrm{Cu}, \mathrm{Zn}, \mathrm{Al}, \mathrm{As}, \mathrm{Ba}, \mathrm{Br}, \mathrm{Ca}, \mathrm{Fe}, \mathrm{Pb}, \mathrm{Mg}$ and $\mathrm{Na}$ ) had the highest median concentrations in the downstream sediments.

Concentrations of $\mathrm{Cu}, \mathrm{Pb}$ and $\mathrm{Zn}$ in sediments in winter were higher than in summer due to the dissolution of previously precipitated solid phases in stream beds in the summer period. Fine contaminated particles in soils of mining areas located upstream can also contribute to the high concentrations of those elements in sediments as they can be mobilized, in suspension by high water flow, and latter deposited in the downstream sediments.

Lead concentration in sediment samples collected in the Chança dam was higher near the mine sources, whereas $\mathrm{Zn}$ concentration was higher in sediments collected in the area downstream occupied by a bigger water body in the Chança dam. Zinc showed higher mobility than $\mathrm{Pb}$, being mainly accumulate on downstream sediments.

Near the mouth $\mathrm{Cu}, \mathrm{As}, \mathrm{Pb}$ and $\mathrm{Zn}$ concentrations were higher probably due to different sources not just mining and the interaction of fresh with marine water that forced precipitation.

Zinc was the element that showed the highest mobility in the Lower sector of Guadiana River basin, especially if compared to $\mathrm{Pb}$.

Table 7

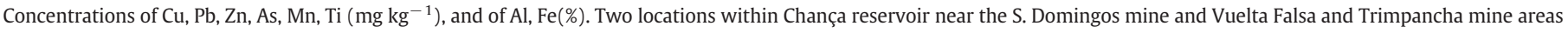
and two samples within the reservoir but further way from the previous ones.

\begin{tabular}{|c|c|c|c|c|c|c|c|c|c|}
\hline Sample in Chança dam & Site within the dam & $\mathrm{Cu}$ & $\mathrm{Pb}$ & $\mathrm{Zn}$ & $\mathrm{Al}$ & As & $\mathrm{Fe}$ & Mn & $\mathrm{Ti}$ \\
\hline 559SD09 & Downstream of S. Domingos mine & 258.00 & 366.00 & 251.00 & 3.89 & 392.00 & 5.45 & 444.00 & 0.52 \\
\hline 567SD01 & Dowstream of 559SD09 in bigger water body & 176.00 & 23.00 & 512.00 & 4.39 & 12.20 & 3.59 & 1290.00 & 0.54 \\
\hline 95830SD & Downstream of several mines in Chança influence & 30.00 & 25.00 & 87.00 & 4.81 & 15.90 & 4.57 & 973.00 & 0.73 \\
\hline 95844SD & Downstream of 95830SD in bigger water body & 42.00 & 24.00 & 232.00 & 2.42 & 9.80 & 3.11 & 825.00 & 0.38 \\
\hline
\end{tabular}


Aluminium mobility seemed to be dependent on the grain size of the particles where it was included. Variations on the mobility of Fe, Mn and Ti might be related to water flow, temperature, dissolution and precipitation conditions. Concentrations of elements such as $\mathrm{As}, \mathrm{Cu}$ and $\mathrm{Pb}$ were more related with the sulphide mineralizations proximity although $\mathrm{Pb}$ proved to be consistently the less mobile.

\section{References}

Batista, M.J., Martins, L., Locutura, J., Bel-Lan, A., Bebianno, M.J., Nieto, J.M., Abreu, M.M., Shepherd, T., Condesso-Melo, T., Del Valls-Casillas, A., Trancoso, A., De Oliveira, D., Matos, J., Cravo, A., Serafim, A., Company, R., Delgado, J., Barrosinho, J., 2007. O Pb como indicador de vulnerabilidade ambiental na Faixa Piritosa Ibérica (in Portuguese). Final Report of UTPIA project, (SP5.P9/02) INTERREG IIIA + 3 Anexos.

Batista, M.J., Locutura, J., Matos, J.X., De Oliveira, D., Bel-Lan, A., Martins, L., 2010. Mobilidade do $\mathrm{Pb}$ nos sedimentos do sector inferior da bacia do rio Guadiana (in Portuguese). Geosciences on-line Journal e-Terra 9 (13) (ISSN 1645-0388).

Chao, T.T., Theobald Jr., P.K., 1976. The significance of secondary iron and manganese oxides in geochemical exploration. Economic Geology 71, 1560-1569.

Chopin, E.I.B., Alloway, B.J., 2007. Distribution and mobility of trace elements in soils and vegetation around the mining and smelting areas of Tharsis, Ríotinto and Huelva, Iberian Pyrite Belt, SW Spain. Water, Air, and Soil Pollution 182, 245-261.

Company, R.M.S., Serafim, A., Lopes, B., Cravo, A., Shepherd, T.J., Pearson, G., Bebianno, M.J., 2008. Using biochemical and isotope geochemistry to understand the environmental and public health implications of lead pollution in the lower Guadiana River, Iberia: a freshwater bivalve study. Science of the Total Environment 405 (1-3), 109-119.

Davis, J.C., 1986. Statistics and Data Analysis in Geology, Second edition. Wiley, New York.

Delgado, J., Nieto, J.M., Boski, T., 2010. Analysis of the spatial variation of heavy metals in the Guadiana Estuary sediments (SW Iberian Peninsula) based on GIS mapping techniques. Estuarine, Coastal and Shelf Science 88, 71-83.

Delgado, J., Barba-Brioso, C., Nieto, J.M., Boski, T., 2011. Speciation and ecological risk of toxic elements in estuarine sediments affected by multiple anthropogenic contributions (Guadiana saltmarshes, SW Iberian Peninsula): I. Surficial sediments. Science of the Total Environment 409 (19), 3666-3679.

Feio, M., 1951. A evolução do relevo do Baixo Alentejo e Algarve (in Portuguese). Comunicações Serviços Geológicos Portugal XXXII 2 ${ }^{\underline{a}}$ parte, pp. 303-477.

Galán, E., Fernández-Caliani, J.C., González, I., Aparicio, P., Romero, A., 2008. Influence of geological setting on geochemical baselines of trace elements in soils. Application to soils of South-West Spain. Journal of Geochemical Exploration 98, 89-106.
Hall, J.R., Reynolds, B., Sparks, T., Colgan, A., Thornton, I., McGrath, S.P., 2001. The relationship between topsoil and stream sediment heavy metal concentrations and acidification. Water, Air, and Soil Pollution 130, 1067-1072.

Jones, R.J.A., Hiederer, R., Rusco, E., Loveland, P.J., Montanarella, L., 2004. The Map of Organic Carbon in Topsoils in Europe: Version 1.2-September 2003. Special Publication, 72. S.P.I.04.72, Ispra.

Kabata-Pendias, A., Pendias, H., 2001. Trace elements in soils and plants, 3rd edition. CRC Press, Inc., Boca Raton, Florida.

Leistel, J.M., Marcoux, E., Thieblemont, D., Quesada, C., Sanchez, A., Almodovar, G.R. Pascual, E., Saez, R., 1997. The volcanic-hosted massive sulphide deposits of the Iberian Pyrite Belt. Mineralium Deposita 33 (1-2), 2-30.

Levinson, A.A., 1980. Introduction to Exploration Geochemistry. Applied Publishing Ltd, Wilmette, Illinois.

Leyva, F., Ramirez, J., 1979. Mapa geológico de España a escala 1/50.000. Hoja nº 998 Ayamonte; IGME

Nriagu, J.O., 1990. Global metal pollution. Poisoning the biosphere. Environment 32 7-33.

Olade, M.A., 1987. Dispersion of Cadmium, Lead and Zinc in Soils and Sediments of a Humid Tropical Ecosystem in Nigeria. In: Hutchinson, T.C., Meema, K.M. (Eds.), Lead, Mercury, Cadmium and Arsenic in the Environment, Scope, 31. Wiley, New York, pp. 303-313.

Oliveira, J., 1990. Stratigraphy and syn-sedimentary tectonism in the South Portuguese Zone. In: Dallmeyer, R.D., Martinez Garcia, E. (Eds.), Pre-Mesozoic Geology of Iberia. Springer, Berlin, pp. 334-347.

Pérez-López, R., Delgado, J., Nieto, J.M., Márquez-García, B., 2010. Rare earth element geochemistry of sulphide weathering in the São Domingos mine area (Iberian Pyrite Belt): a proxy for fluid-rock interaction and ancient mining pollution. Chemical Geology 276, 29-40.

Ribeiro, A., Quesada, C., Dallmeyer, R.D., 1990. Geodynamic evolution of the Iberian massif. In: Dallmeyer, R.D., Martinez Garcia, E. (Eds.), Pre-Mesozoic Geology of Iberia. Springer, Berlin, pp. 383-395.

Rose, A.W., Hawkes, H.E., Webb, J.S., 1979. Geochemistry in Mineral Exploration. Academic Press, New York.

Salazar Rincón, A., 2006. Mapa geológico 1/50.000 de Huelva-Los Caños- IGME.

Taylor, S.R., 1964. Abundance of chemical elements in the continental crust. A new table. Geochimica et Cosmochimica Acta 28, 1273-1286.

Turekian, K.K., Wedepohl, K.H., 1961. Distribution of the elements in some major units of the earth's crust. Geological Society of America Bulletin 72, 175-192.

Violante, A., Cozzolino, V., Perelomov, L., Caporale, A.G., Pigna, M., 2010. Mobility and bioavailability of heavy metals and metalloids in soil environments. Journal of Soil Science and Plant Nutrition 10 (3), 268-292.

Wilson, M.J., Bell, N., 1996. Acid deposition and heavy metals. Applied Geochemistry 11 (1-2), 133-137. 